\title{
PELATIHAN PENYUSUNAN PENELITIAN TINDAKAN UNTUK GURU BIMBINGAN DAN BIMBINGAN
}

\section{TRAINING FOR THE DRAFTING OF ACTION RESEARCH FOR GUIDANCE AND COUNSELING TEACHERS}

\author{
Agus Supriyanto $^{1)^{*}}$, Agungbudiprabowo ${ }^{2)}$, Sri Hartini ${ }^{3)}$ \\ ${ }^{1)}$ Fakultas Keguruan dan Ilmu Pendidikan, Universitas Ahmad Dahlan, \\ email: agus.supriyanto@bk.uad.ac.id \\ ${ }^{2)}$ Fakultas Keguruan dan Ilmu Pendidikan, Universitas Ahmad Dahlan, \\ email:, agungbudiprabowo@ bk.uad.ac.id \\ ${ }^{3)}$ Fakultas Keguruan dan Ilmu Pendidikan, Universitas Ahmad Dahlan, \\ email: sri.hartini@bk.uad.ac.id
}

\begin{abstract}
ABSTRAK
Kompetensi konselor sekolah untuk menemukan pengetahuan baru dalam bimbingan dan konseling disebut kemampuan penelitian. Seorang konselor sekolah di Indonesia sangat paham akan kompetensinya melakukan penelitian. Faktanya, konselor sekolah meneliti tanpa merancang proposal karena memenuhi akreditasi sekolah. Pelatihan konselor sekolah membuat proposal penelitian merupakan salah satu caranya. Metode tersebut menggunakan pemberian informasi, pelatihan, pendampingan, dan brainstorming dalam merancang proposal penelitian. Proses pengabdian masyarakat melalui kegiatan pelatihan agar guru BK memiliki kemampuan merancang latar belakang, identifikasi masalah, batasan masalah, rumusan masalah, tujuan penelitian, manfaat penelitian, kajian pustaka, kerangka berpikir, dan metode penelitian tindakan di bidangnya. bimbingan dan konseling. Proses mengembangkan metode penelitian dengan menentukan subjek penelitian, menyusun instrumen penelitian, dan pengetahuan yang berkaitan dengan validitas, reliabilitas, dan analisis data. Guru Bimbingan dan Konseling dapat menggunakan kutipan yang benar dan menyusun bibliografi dengan aplikasi Zotero dengan google scholar. Hasil dari kegiatan pengabdian kepada masyarakat terdapat fenomena yang dapat diciptakan dalam penelitian bimbingan dan konseling serta mengembangkan kemampuan guru bimbingan dan konseling dalam menyusun penelitian tindakan bimbingan dan konseling. Bank proposal penelitian dengan cara online untuk mengumpulkan desain proposal penelitian bimbingan dan konseling.
\end{abstract}

Kata kunci: Penelitian Tindakan, Bimbingan dan Konseling, Pelatihan

\section{ABSTRACT}

School counsellor competencies to find new knowledge in guidance and counselling called research ability. A school counsellor in Indonesia understands well about their competence to do research. The fact is that school counsellors research without designing proposals because they meet school accreditation. School counsellors training to create research proposals is one way. The method uses the provision of information, training, mentoring, and brainstorming in designing research proposals. The process community service through training activity so that guidance and counselling teachers have the ability in designed of background, problem identification, problem boundaries, problem formulation, research objectives, research benefits, literature review, thinking framework, and action research methods in the field of guidance and counselling. Process develop research methods by determining research subjects, compiling research instruments, and knowledge related to validity, reliability, and data analysis. Guidance and counselling teachers can use correct citations and compile a bibliography with the Zotero application with google scholar. The result of community service the activity is that there are phenomena that can be created in guidance and counselling research and develop guidance and counselling teacher ability in drafting action research guidance and counselling. Research proposal banks in a way online to collect design of guidance and counselling research proposals.

Keywords: Action research, Guidance and counseling, Training 


\section{PENDAHULUAN}

Konselor sekolah memiliki peran sebagai konselor profesional dan terlibat dalam pelaksanaan pendidikan [1]. Keterlibatan konselor dalam pengembangan pendidikan di sekolah berbasis penelitian. Penelitian tindakan dilakukan oleh konselor sekolah menggunakan literasi yang berguna untuk menyelaraskan program bimbingan dan konseling dengan implementasinya [2]. Hasil penelitian yang dilaksanakan oleh konselor sekolah berguna untuk merancang kebutuhan, problematika, program pencegahan, dan intervensi bagi siswa. Intervensi konseling menghasilkan ukuran efek yang cukup besar di bidang disiplin, pemecahan masalah, dan peningkatan pengetahuan pada diri siswa [3].

Kompetensi konselor sekolah dalam penelitian bimbingan dan konseling memiliki empat indikator. Indikator konselor yang memiliki kompetensi dalam penelitian bimbingan dan konseling yaitu memahami berbagai jenis dan metode penelitian, kemampuan untuk merancang penelitian, melakukan penelitian, dan menggunakan hasil penelitian dengan mengakses jurnal pendidikan dan bimbingan dan konseling [4]. Kompetensi konselor dalam penelitian bimbingan dan konseling perlu dikembangkan. Dasar berkembangnya kompetensi diperlukan pengembangan diri pada diri konselor [5].

Kelebihan konselor di Indonesia adalah memahami tentang kompetensi professional dirinya sebagai konselor sekolah untuk melaksanakan pelayanan bimbingan dan konseling dengan kategori tinggi $(71 \%)$ atau telah paham [6]. Fakta pemahaman diri konselor berbeda dengan realita pelaksanaan dari kompetensi profesional pada diri konselor. Realita dari kompetensi profesional konselor hanya pada kategori cukup positif [7]. Hal lain mengungkapkan bahwa sebagian besar guru bimbingan dan konseling sebagai konselor sekolah telah melakukan kegiatan untuk meningkatkan kompetensi profesionalnya, namun masih belum ada yang melakukan penelitian bimbingan dan konseling [8].

Fakta konselor sekolah di jenjang Sekolah Muhammadiyah di Kabupaten Bantul menunjukkan bahwa konselor sekolah telah melaksanakan penelitian tanpa merancang proposal penelitian. Analisis situasi ini menimbulkan kecenderungan bahwa konselor sekolah hanya mengejar akreditasi sekolah dengan menyusun laporan penelitian tanpa perencanaan yang matang (proposal penelitian). Peningkatan kemampuan profesional konselor sekolah untuk menyusun proposal penelitian secara matang dapat diberdayakan dalam program pemberdayaan dan pelatihan konselor sekolah dalam menyusun proposal penelitian tindakan bimbingan dan konseling (PTBK).

Pemberdyaaan masyarakat bertujuan untuk pengembangan masyarakat melalui bimbingan sosial berdasarkan pengalaman akademik dan lapangan [9]. Tujuan khusus dari program ini adalah pengembangan proposal penelitian, partisipasi dalam 
program, dan penguatan kapasitas guru

bimbingan dan konseling untuk Menyusun dan mendesai proposal penelitian pada bidang keilmuan bimbingan dan konseling melalui penelitian Tindakan bimbingan dan konseling (PTBK). Tiga indikator pengembangan yaitu penciptakan suasana yang memungkinkan guru bimbingan dan konseling berkembang, penguatan potensi guru bimbingan dan konseling melalui langkah-langkah nyata yang membuat guru bimbingan dan konseling semakin berdaya saing, serta pelindungan dan pembelaan pada kepentingan dan eksistensi guru bimbingan dan konseling [10].

Pelatihan pada guru menjadi solusi utama untuk mengembangkan kemampuan dan keterampilan dalam menyusun proposal penelitian. Tujuan pelatihan adalah peningkatan pengetahuan, ketrampilan, kinerja, perilaku individu, kelompok, atau organisasi [11]. Dampak pelatihan dalam program ini adalah kepuasan kerja dari konselor di sekolah dalam pelayanan bimbingan dan konseling [12].

\section{METODE PELAKSANAAN KEGIATAN}

Pengabdian kepada masyarakat sebagai bagian dari program pelatihan pada guru bimbingan dan konseling. Metode yang digunakan dalam program ini adalah dengan melalui metode penyuluhan, pelatihan, mentor, dan branstorming untuk menyusun draft proposal penelitian tindakan bimbingan dan konseling (PTBK). Pengabdian kepada masyarakat memiliki sasaran yaitu guru bimbingan dan konseling yang bekerja di Sekolah Menengah
Muhammadiyah di Kabupaten Bantul.

Lokasi pengabdian berasa di laboratorium multimedia yang memiliki sarana pendukung internet dan komputer dalam menyusun proposal penelitian tindakan bimbingan dan konseling (PTBK). Prasarana yang mendukung adalah google scholar untuk mendukung sitasi dan penuisan kutipan. Observasi adalah instrument utama dalam menunjang keaktifan program pelatihan. Kuantitas dan kualitas proposal diukur untuk melihat kelayakann proposal yang telah disusun. Hasil dari penyusunan proposal dari guru bimbingan dan konseling dipresentasikan untuk menerima review hasil penyusunan proposal.

Proses pengabdian kepada masyarakat melalui lima tahapan. Tahap pertama adalah guru bimbingan dan konseling dapat mengidentifikasi masalah yang ada di sekolah terkait siswa dan guru bimbingan dan konseling, kemudian menyusun draft final judul penelitian tindakan bimbingan dan konseling (PTBK). Tahap kedua adalah melatih supaya mampu menyusun pendahuluan yang berupa latar belakang penelitian, identifikasi masalah, Batasan masalah, rumusan masalah, tujuan penelitian, dan manfaat penelitian. Tahap ketiga adalah melatih supaya mampu menyusun kajian teori dan kerangka penelitian. Tahap ketiga adalah melatih untuk mampu mendesain penelitian dengan metode penelitian tindakan dengan metode, subjek, variable, instrument penelitian yang 145 
valid dan reliabel, serta proses analisis data. Tahap terakhir adalah kemampuan guru menggunakan apliasi Zotero sebagai aplikasi yang mendukung penyusunan daftar pustaka dan cara mengutip yang benar.

\section{HASIL DAN PEMBAHASAN}

Pengabdian kepada masyarakat tentang program pelatihan bagi guru bimbingan dan konseling untuk menyusun proposal penelitian tindakan bimbingan dan konseling (PTBK). Empat metode yang gunakan tim pengabdian yaitu penyuluhan, pelatihan, mentor, dan branstroming. Setiap metode memiliki peran masing-masing dalam pengembangan pengetahuan, pemahaman, keterampilan, dan produk dari setiap guru.

Kegiatan pengabdian kepada masyarakat (PPM) melalui program pelatihan penyusunan draft proposal bagi guru bimbingan dan konseling di Sekolah Menengah Muhammadiyah Se- Kabupaten Bantul diawali melalui metode penyuluhan. Tim pelaksana melaksanakan informasi tentang kompetensi guru bimbingan dan konseling dalam menyusun dan melaksanakan penelitian. Pentingnya penelitian pendidikan oleh guru dapat mempengaruhi pengetahuan guru untuk menerapkan praktik dan pelayanan kepada siswa [13].

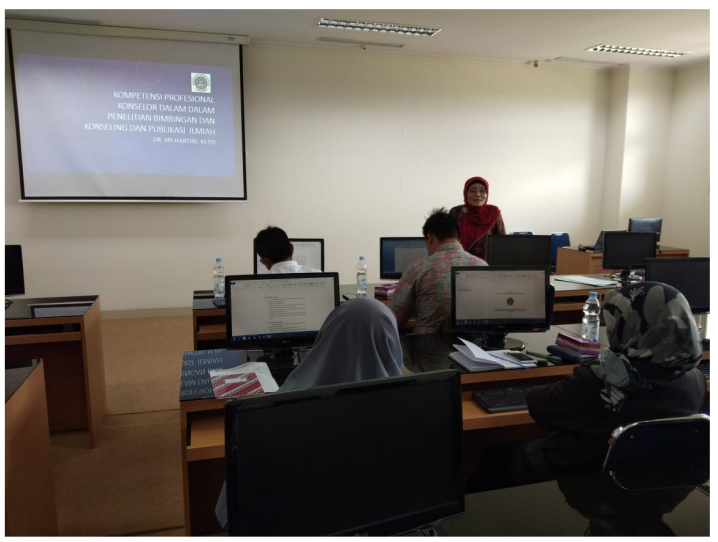

Gambar 1. Penyuluhan Tentang Kompetensi Guru Bimbingan dan Konseling dalam Penelitian

Guru dibekali kompetensi dalam meneliti. Pembekalan kompetensi guru bimbingan dan konseling dalam meneliti melalui klinik proposal [14]. Guru juga dibekali informasi supaya memahami dan mengimplementasikan berbagai jenis penelitian, khususnya penelitian tindakan bimbingan dan konseling (PTBK). Penelitian tindakan bimbingan dan konseling (PTBK) digunakan oleh peneliti dosen dan praktisi, yaitu guru bimbingan dan konseling untuk melakukan proses penyelidikan dan melaksanakan penelitian terapan [15]. Pemilihan penelitian tindakan oleh guru bimbingan dan konseling di dalam pelatihan supaya guru dapat mengaktifkan siswa dalam membuat keputusan melalui proses penelitian untuk tujuan utama memberikan perubahan sosial pada diri siswa dengan tindakan spesifik sebagai tujuan akhir penelitian tindakan [16].

Setelah menjelaskan tentang kompetensi guru bimbingan dan konseling di dalam penelitian dan berbagai jenis penelitian. Tim pengabdian mengadakan kegiatan pelatihan bagi guru bimbingan dan konseling tentang 146

http://logista.fateta.unand.ac.id 
semua fase proses penyusunan proposal penelitian tindakan bimbingan dan konseling (PTBK). Fase-fase penyusunan proposal dari memilih topik, meninjau literatur, mengumpulkan, menganalisis, dan melaporkan data, dan proses menyajikan laporan [17].

Fase pertama dalam pelatihan penyusunan proposal penelitian tindakan adalah memilih topik penelitian. Guru bimbingan dan konseling dalam pelatihan bersama tim pengabdian menceritakan fenomena-fenomena yang terjadi di sekolah masing-masing dan menemukan topik masalah. Topik masalah yang disusun menemukan fakta sebagai dasar dari variabel terikat, sehingga guru bimbingan dan konseling dapat mengidentifikasi masalah sesuai fakta pada siswa di sekolah dan membuat batasan masalah.

Metode braintroming dengan cara pendampingan dapat menambah wawasan guru bimbingan dan konseling tentang pokok-pokok pikiran yang harus disusun di dalam latar belakang penelitian tindakan bimbinga dan konseling (PTBK). Pokokpokok pikiran disusun melalui proses identifikasi masalah dari fenomenafenomena yang terjadi di sekolah, khususnya pada guru bimbingan dan konseling. Guru bimbingan dan konseling melakukan refleksi terkait kinerja mereka yang berkaitan dengan permasalahan pada diri siswa. Kemudian guru bimbingan dan konseling menyusun desain tindakan untuk mengatasi masalah yang dialami oleh siswa sebagai variabel bebas [18].

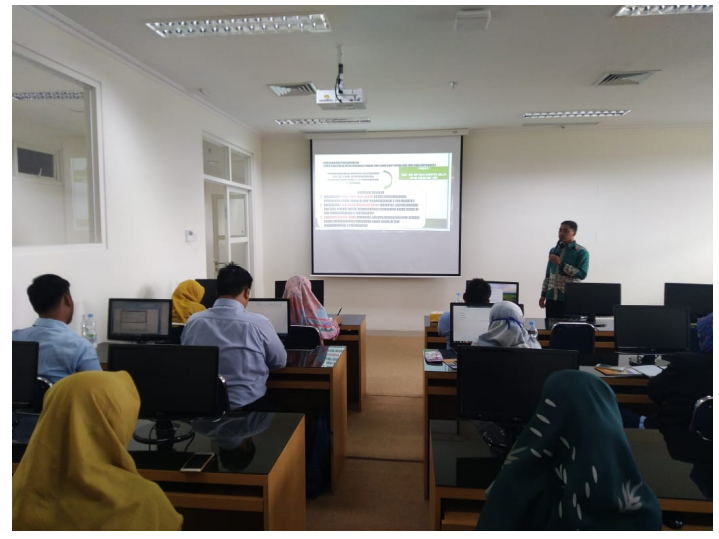

Gambar 2. Pelatihan Penyusunan Latar Belakang Penelitian Bimbingan dan Konseling

Fase pertama dalam pelatihan dilanjutkan dengan menyusun latar belakang masalah, identifikasi masalah, Batasan masalah, rumusan masalah, tujuan penelitian, serta manfaat penelitian. Penyusunan latar belakang penelitian dalam penelitian tindakan dengan cara mendekati masalah penelitian berdasarkan fenomena dan pengembangan teori masalah yang mendukung [19]. Kemudian guru bimbingan dan konseling menyusun rumusan masalah secara komprehensif dengan menciptakan proses terstruktur yang memenuhi tujuan desain penelitian yang diturunkan secara teoritis [20]. Terakhir dalam pelatihan penyusunan proposal pada bagian pendahuluan, guru bimbingan dan konseling dapat menyusun manfaat penelitian secara operasional dan manfaat langsung dari hasil penelitian. Manfaat yang ada baik memberikan perlindungan bagi hasil penelitian dan berkembangnya potensi untuk mengatasi masalah secara teoritis dan praktis [21].

Fase kedua dalam program pelatihan 
adalah guru bimbingan dan konseling sudah mampu menyusun tinjauan literatur. Tinjauan literatur berguna untuk meninjau asal-usul teori, mengeksplorasi sikap awal yang diambil oleh peneliti, menguraikan dasar pemikiran yang terkait dengan posisi tertentu, serta mendiskusikan ide untuk merekonsiliasi perspektif peneliti [22]. Hasil dari penyusunan tinjauan literatur, guru bimbingan dan konseling menyusuna kerangka berpikir dan hipotesis tindakan dalam penelitian tindakan bimbingan dan konseling (PTBK). Penyusunan kerangka berpikir dalam penelitian berdasarkan tinjauan literatur dapat mengembangkan kemampuan berpikir kritis guru. Pengembangan kompetensi berpikir kritis di dalam kerangka bepikir penelitian pada guru bimbingan dan konseling sebagai peneliti untuk memberikan bukti atau argumen logis untuk mendukung penilaian, pilihan, klaim, atau pernyataan [23]. Hipotesis tindakan dalam proposal penelitian tindakan bimbingan dan konseling (PTBK) yang disusun berdasarkan proses persepsi, kognitif, dan motorik untuk mengoordinasikan tindakan yang akan dilaksanakan dengan meninjau konsep- konsep teoretis untuk memberikan gambaran terstruktur penelitian tindakan [24].

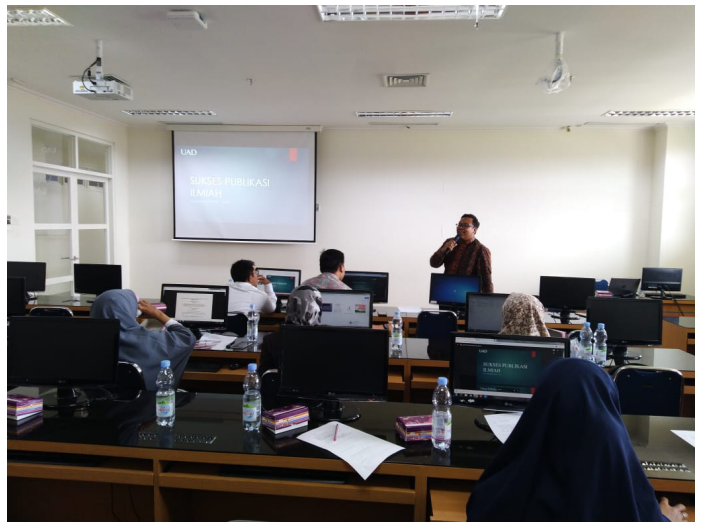

Gambar 3. Pelatihan Penyusunan Kajian Teori dan Kutipan menggunakan Zotero dan Google Scholar

Fase ketiga adalah penyusunan metode penelitian dengan desain penelitian tindakan bimbingan dan konseling (PTBK). Penentuan subjek penelitian, instrument penelitian, dan proses validitas dan atau reliabilitas, serta analisis data disusun dalam proposal penelitian oleh guru bimbingan dan konseling. Metodologi penelitian yang disusun sesungguhnya mendukung manfaat penelitian [25].

Hasil program ini adalah peningkatan kemampuan guru dalam menyusun proposal penelitian tindakan bimbingan dan konseling (PTBK) dan terkumpulnya proposal penelitian tindakan dalam bank proposal. Peningkatkan kemampuan guru melalui lokakarya proposal PTK menunjukkan keberhasilan dalam mengembangkan proposal PTK [26]. Bank proposal penelitian juga menjadi berkumpulnya file-file proposal penelitian tindakan bimbingan dan konseling (PTBK) yang tersimpan oleh tim pengabdian kepada masyarakat. Proposalproposal ini menjadi bahan pelatihan bagi guru bimbingan dan konseling di masa depan. Program ini mendukung Program 
Pemerintah terkait Pendidikan Profesi Guru dan mencetak guru professional sebagai peneliti di sekolah masing-masing.

Terakhir, guru bimbingan dan konseling berlatih menyusun kutipan melalui google scholar dan aplikasi zotero. Kelengkapan hasil kutipan yang diambil dari sumber kutipan asli yang dapat meningkatkan kesadaran untuk memeriksa kutipan melalui google scholar [27]. Google cendekia juga sebagai alternatif atau pelengkap dalam kajian literature yang mendukung [28]. Zotero digunakan dalam pelatihan sebagai perangkat lunak gratis yang dapat membuat mengelola informasi daftar pustaka dengan mengumpulkan referensi, yang terintegrasi dengan microsoft word [29][30].

\section{KESIMPULAN}

Guru bimbingan dan konseling memiliki kompetensi dalam merancang proposal penelitian bimbingan dan konseling. Proposal penelitian tindakan yang disusun oleh guru bimbingan dan konseling memiliki lima indikator yaitu desain pendahuluan, desain tinjauan teori, metode penelitian, daftar pustaka, dan instrument penelitian. Hasil penyusunan proposal dikumpulkan dalam bank proposal dan menjadi kumpulan proposal yang menunjang pelaksanaan penelitian di sekolah bagi guru bimbingan dan konselin. penelitian bimbingan dan konseling.

Proposal penelitian tindakan yang disusun oleh guru bimbingan dan konseling memiliki lima indikator yaitu desain pendahuluan, desain tinjauan teori, metode penelitian, daftar pustaka, dan instrument penelitian. Hasil penyusunan proposal dikumpulkan dalam bank proposal dan menjadi kumpulan proposal yang menunjang pelaksanaan penelitian di sekolah bagi guru bimbingan dan konseling.

\section{UCAPAN TERIMAKASIH}

Tim pengabdian kepada masyarakat mengucapkan terimakasih kepada Lembaga Penelitian dan Pengabdian kepada Masyarakat (LPPM) di Universitas Ahmad Dahlan (UAD). LPPM UAD telah memberikan dukungan berupa dana dan kesempatan bagi tim untuk mengembangkan kompetensi guru di dalam penelitian bidang bimbingan dan konseling. Dampak hasil penelitian adalah peningkatan pengetahuan dan kemampuan guru bimbingan dan konseling untuk menyusun proposal penelitian sebelum melaksanakan penelitian.

\section{REFERENSI}

[1] S. M. Reiner, R. D. Colbert, and R. Pérusse, "Teacher perceptions of the professional school counselor role: A national study," Prof. Sch. Couns., vol. 12, no. 5, p. 2156759X0901200507, 2009.

[2] C. A. Dahir and C. B. Stone, "School counselor accountability: The path to social justice and systemic change," $J$. Couns. Dev., vol. 87, no. 1, pp. 12-20, 2009.

[3] S. C. Whiston and R. F. Quinby, "Review of school counseling outcome research," Psychol. Sch., vol. 46, no. 3, pp. 267-272, 2009.

[4] A. Supriyanto, S. Hartini, S. Syamsudin, and A. Sutoyo, "Indicators of professional competencies in research of Guidance and Counseling Teachers," Couns. J. Bimbing. Dan Konseling, vol. 9, no. 1, pp. 53-64, 2019. 
[5] N. Hidayah, "Process-Audit dalam Penyelenggaraan Pendidikan Akademik Jenjang S-1 Bimbingan dan Konseling," J. Pendidik. Dan Pembelajaran JPP, vol. 17, no. 2, pp. 129-139, 2012.

[6] A. A. Malik and K. Kurniawan, "Tingkat Pemahaman Konselor Tentang Kompetensi Professional dalam Pelayanan Bimbingan dan Konseling," Indones. J. Guid. Couns. Theory Appl., vol. 4, no. 2, 2015.

[7] R. Setyoningtyas, "Persepsi guru bk tentang kompetensi konselor di sekolah dasar swasta kota semarang," $\mathrm{PhD}$ Thesis, Universitas Negeri Semarang, 2014.

[8] H. Nurrahmi, "Kompetensi profesional guru bimbingan dan konseling," $J$. Dakwah Alhikmah, vol. 9, no. 1, pp. 4555, 2015.

[9] A. Fahrudin, "Pemberdayaan, Partisipasi dan Penguatan Kapasitas Masyarakat," Bdg. Hum., 2011.

[10] M. Noor, "Pemberdayaan masyarakat," CIVIS, vol. 1, no. 2/Juli, 2011.

[11] B. Santoso, Skema dan Mekanisme Pelatihan: Panduan Penyelenggaraan Pelatihan. Yayasan Terumbu Karang Indonesia, 2010.

[12] F. S. Lodjo, "Pengaruh pelatihan, pemberdayaan dan efikasi diri terhadap kepuasan kerja," J. EMBA J. Ris. Ekon. Manaj. Bisnis Dan Akunt., vol. 1, no. 3, 2013.

[13] S. K. Abell, K. Appleton, and D. L. Hanuscin, Handbook of research on science education. Routledge, 2013.

[14] W. Darmalaksana, "Urgensi klinik proposal: Persiapan pengusulan penelitian standar Litapdimas," 2017.

[15] E. T. Stringer, Action research. Sage publications, 2013.

[16] C. MacDonald, "Understanding participatory action research: A qualitative research methodology option," Can. J. Action Res., vol. 13, no. 2, pp. 34-50, 2012.

[17] A. P. Johnson, "A short guide to action research," 2012.

[18] M. K. Sein, O. Henfridsson, S. Purao, M. Rossi, and R. Lindgren, "Action design research," MIS Q., pp. 37-56,
2011.

[19] A. Luse, B. E. Mennecke, and A. M. Townsend, "Selecting a research topic: A framework for doctoral students," Int. J. Dr. Stud., vol. 7, p. 143, 2012.

[20] M. Baer, K. T. Dirks, and J. A. Nickerson, "Microfoundations of strategic problem formulation," Strateg. Manag. J., vol. 34, no. 2, pp. 197-214, 2013.

[21] A. Friedman, E. Robbins, and D. Wendler, "Which benefits of research participation count as 'direct'?," Bioethics, vol. 26, no. 2, pp. 60-67, 2012.

[22] C. Dunne, "The place of the literature review in grounded theory research," Int. J. Soc. Res. Methodol., vol. 14, no. 2, pp. 111-124, 2011.

[23] E. R. Lai, "Critical thinking: A literature review," Pearsons Res. Rep., vol. 6, pp. 40-41, 2011.

[24] G. Knoblich, S. Butterfill, and N. Sebanz, "Psychological research on joint action: theory and data," in Psychology of learning and motivation, vol. 54, Elsevier, 2011, pp. 59-101.

[25] T. Anderson and J. Shattuck, "Designbased research: A decade of progress in education research?," Educ. Res., vol. 41, no. 1, pp. 16-25, 2012.

[26] A. S. S. Ridwan, "Peningkatan Mutu Dikalangan Guru SD Gugus Diponegoro kecamatan Ungaran Barat Dengan Kemampuan Penyusunan Proposal PTK melalui Workshop," $J$. Penjaminan Mutu, vol. 3, no. 1, pp. 2330, 2017.

[27] L. S. Adriaanse and C. Rensleigh, "Web of science, scopus and Google Scholar," Electron. Libr., 2013.

[28] J. van Aalst, "Using Google Scholar to estimate the impact of journal articles in education," Educ. Res., vol. 39, no. 5, pp. 387-400, 2010.

[29] P. Fernandez, "Zotero: information management software 2.0," Libr. Hi Tech News, 2011.

[30] J. D. Murimboh and C. R. Hollingdale, Zotero: a reference manager for everyone. ACS Publications, 2012. 